\title{
MRI Cervical Image Analysis with Fat Suppression Techniques Between Sequent Turbo Invers Recovery Magnitude (TIRM) and Fat Saturations (Fat Sat) on Degenerative Disc Disease at Haji Hospital Surabaya
}

\author{
Vita Arinda Ayu Putri Nata ${ }^{1}$, Suryani Dyah Astuti ${ }^{1}$, R. Arif Wibowo ${ }^{1}$ \\ ${ }^{1}$ Department of Physics, Faculty of Science and Technology, Universitas Airlangga, Surabaya 60115, Indonesia
}

Article History

Received : 05 April 2021, Revised : 07 May 2021, Accepted : 26 May 2021, Online : June 2021

\begin{abstract}
This study aimed to analyze the difference of image information and determine the better image quality between the Turbo Invers Recovery Magnitude (TIRM) and Fat Saturation (Fat Sat) techniques on cervical MRI examination at Haji Hospital Surabaya. The samples of this study were one female and three male patients. The obtained data were ROI of the vertebral body tissue, intervertebral discs, spinal cord, and then calculated as SNR and CNR values. SNR and CNR values were statistically tested using Paired T-Test on SPSS 2.5. The Paired T-Test results showed a significant difference between the TIRM and Fat Sat techniques, $p>0.05$. SNR and CNR average values also proved that the Fat Sat technique had more optimal image quality than the TIRM technique.
\end{abstract}

\section{INTRODUCTION}

Magnetic resonance imaging (MRI) is a medical imaging technique that used magnetic fields and radiofrequency to visualize and analyze tissues (muscles, ligaments, cartilage), blood flow, and metabolic functions. In clinical application, the magnetic field magnitude range from 0.3 Tesla -3 Tesla [1]. MRI examination is including head, neck, thoracic, abdomen, pelvis, vertebrae, upper extremities, and lower extremities. The cervical examination is one of the typical vertebrae examinations.

Cervical vertebrae consist of corpus vertebrae, intervertebral disc, spinal cord, and fat, so it is challenging to differentiate fat and soft tissue in some conditions. Fat surrounds many anatomical structures, and in some tissues, fat forms a molecular component with hydrogen atoms in liquids. Therefore, Fat-Suppression was developed, namely Turbo Invers Recovery Magnitude (TIRM) and the Fat Saturation (Fat Sat) technique, to overcome these problems.

TIRM is one of the Fat Suppression techniques to reduce fat signals, so the degenerative disc and organ disorders surrounding fat can be appropriately identified. In addition, the TIRM technique produces an image with high contrast and clear (conspicuity) lesions on detecting lesions, bone marrow abnormalities, and degenerative disc (2 Mehta, 1995). TIRM uses a short Time Inverse corresponding to the fat null point, especially the signal null pulse excitation point of the fat, but it often takes a long time with low resolution (Woodward, 1995; 1997).

On the other hand, fat suppression pulses are only applied to tissue (especially fat) and not effectively applicable to air. Hence, the Fat Sat technique suppresses fat signals in large amounts with enhanced contrast media images. Also, Fat Sat minimizes the artifacts misregistration and can be applied to various kinds of imaging sequences. The required time to apply the saturation pulses is $10 \mathrm{msec}$. Thus, Fat Sat generally speeds up the examination time (Delfaut, 1999; Westbrook, 1999).

According to the explanation of the two fat suppression techniques, this study will discuss the image information difference and determining the more optimal image result between the TIRM and Fat Sat technique using MRI 1.5 Tesla. 


\section{MATERIAL AND MethodS}

The data were taken from July to December 2017 at the Radiology Installation of Haji Hospital Surabaya and the Biophysics Laboratory, Faculty of Science and Technology, Universitas Airlangga, Surabaya. This study used a cervical MRI examination on one female patient and three male patients with degenerative disc disease between 2030 years old.

The MRI scanning process was done using two techniques for each sample, the Fat Sat technique, and the TIRM technique. Images from the scanning process were displayed on an MRI computer and used to determine the Region of Interest (ROI) of cerebrospinal fluid tissue, spinal cord, discus, meniscus, and noise. The tissues selection depended on the most tissue composition. The SNR and CNR values were obtained as the interval data from ROI determination and the time of the examination. The data were then statistically tested using Paired T-Test on SPSS software.

Paired T-Test was a parametric test on two paired data that came from the same sample. The data types were interval or ratio data and must be customarily distributed proved by $p>0.05$ of Shapiro Wilk Normality Test for four samples. The data would show no significant difference in Paired T-Test between TIRM and Fat Sat technique if $p<0.05$.

\section{RESULTS AND DISCUSSIONS}

This study aimed to analyze the image information between the TIRM and Fat Sat technique using MRI 1.5 Tesla. The samples were four patients, one female, and three males, between 20-30 years old with degenerative disc disease. The four samples were examined using the TIRM and Fat Sat techniques on Cervical MRI examination with controlled variables. The TIRM technique took $4.05 \mathrm{~s}$ while the Fat Saturation technique $3.20 \mathrm{~s}$.

Each sample generated two MRI images with calculated ROI from an MRI computer. ROI calculation indicated the tissues signal for SNR and CNR calculation and focused on specific tissues, such as cerebrospinal fluid, spinal cord, disc, and meniscus, including signal noise. The ROI area should be the smallest cross-sectional area, homogenous and the slightest standard deviation value. Figure 1 presented the cervical MRI image of sample 1, while Table 1 showed the ROI calculation result of sample 1.

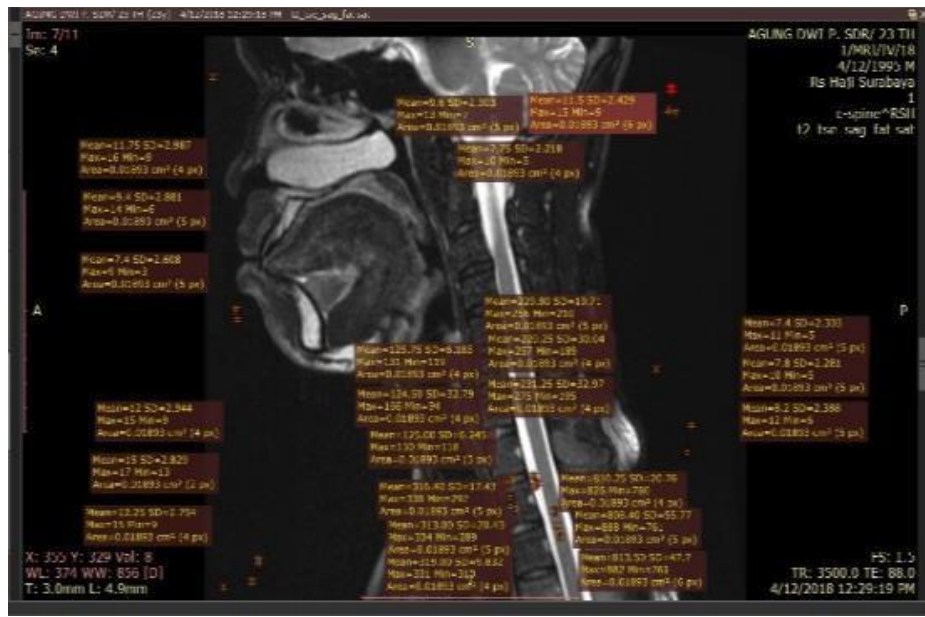

FIGURE 1. Cervical MRI of Sample 1

TABLE 1.. Sample 1 ROI Calculation Results of Cervical MRI.

\begin{tabular}{|c|c|c|c|c|c|c|c|c|c|}
\hline \multirow{2}{*}{ Technique } & \multirow{2}{*}{ ROI } & \multicolumn{4}{|c|}{ ROI OF THE BODY TISSUE } & \multicolumn{4}{|c|}{ BACKGROUND } \\
\hline & & $\begin{array}{c}\text { Cerebrospinal } \\
\text { fluid }\end{array}$ & $\begin{array}{l}\text { Medula } \\
\text { Spinalis }\end{array}$ & Discus & Meniscus & SD1 & SD2 & SD3 & Average \\
\hline \multirow{3}{*}{ Fat Sat } & 1 & 229.8 & 810.25 & 125.75 & 316.4 & \multirow{3}{*}{2.63} & \multirow{3}{*}{2.6} & \multirow{3}{*}{2.54} & \multirow{3}{*}{2.59} \\
\hline & 2 & 220.25 & 808.4 & 124.5 & 313 & & & & \\
\hline & 3 & 231.25 & 813.5 & 125 & 319 & & & & \\
\hline \multirow{3}{*}{ TIRM } & 1 & 71 & 325.5 & 52 & 180 & \multirow{3}{*}{1.61} & \multirow{3}{*}{1.06} & \multirow{3}{*}{2.14} & \multirow{3}{*}{1.6033} \\
\hline & 2 & 62 & 344 & 73 & 176.5 & & & & \\
\hline & 3 & 75 & 344 & 80.5 & 164 & & & & \\
\hline
\end{tabular}


SNR value was the ratio of ROI signal and the average standard of signal deviation background. Both TIRM and Fat Sat techniques had different SNR value. Table 2 showed the SNR values of the samples.

TABLE 2.. SNR Results of Cervical MRI.

\begin{tabular}{cccccc}
\hline \multirow{2}{*}{ Technique } & Sample & Cerebrospinal fluid & Medula Spinalis & Discus & Meniscus \\
\hline \multirow{3}{*}{ Fat Sat } & 1 & 87.7 & 313 & 48.3 & 122.1 \\
\cline { 2 - 5 } & 2 & 104.7 & 45.1 & 46.1 & 40.4 \\
\cline { 2 - 5 } & 3 & 78.6 & 169.8 & 86.7 & 74.4 \\
\cline { 2 - 5 } & 4 & 77.2 & 34.9 & 29.3 & 23.2 \\
\hline \multirow{3}{*}{ TIRM } & Average & 87.05 & 313 & 52.6 & 65.025 \\
\cline { 2 - 5 } & 1 & 43.2 & 210.7 & 42.7 & 108.2 \\
\cline { 2 - 5 } & 2 & 79.4 & 60.7 & 31.6 & 44 \\
\hline & 3 & 44.9 & 54.9 & 30.3 & 34.9 \\
\hline & Average & 60.95 & 58.3 & 30.4 & 42.2 \\
\hline
\end{tabular}

The SNR value was tested statistically using the Shapiro-Wilk Normality Test for samples less than 50 on SPSS to determine the statistical distribution in each tissue. Table 3 presented the significance test result of the normality test.

TABLE 3.. Normality Test Results for SNR

\begin{tabular}{cllc}
\hline \multirow{2}{*}{ Technique } & \multicolumn{1}{c}{ Tissue } & \multicolumn{2}{c}{ Shapiro-Wilk Normality Test } \\
\cline { 2 - 4 } & & Significance $(\boldsymbol{p})$ & Conclusion \\
\hline \multirow{3}{*}{ Fat Sat } & Cerebrospinalfluid & 0.519 & Normal \\
\cline { 2 - 4 } & Medula Spinalis & 0.571 & Normal \\
\cline { 2 - 4 } & Discus & 0.718 & Normal \\
\cline { 2 - 4 } & Meniscus & 0.657 & Normal \\
\hline \multirow{3}{*}{ TIRM } & Cerebrospinalfluid & 0.754 & Normal \\
\cline { 2 - 4 } & Medula Spinalis & 0.765 & Normal \\
\cline { 2 - 4 } & Discus & 0.986 & Normal \\
\cline { 2 - 4 } & Meniscus & 0.761 & \\
\hline
\end{tabular}

The significance value for each tissue were over 0.05 , so the SNR values were normally distributed. The Paired T-Test was then carried out on SPSS to determine the significant difference in each tissue. Table 4 showed that $p>0.05$ and significant differences in each tissue.

TABLE 4.. Paired T-Test Significance Test Result of SNR

\begin{tabular}{clll}
\hline \multirow{2}{*}{ Technique } & \multicolumn{1}{c}{ Tissue } & \multicolumn{2}{c}{ Paired T-Test } \\
\cline { 2 - 3 } & & Significance $(\boldsymbol{p})$ & Conclusion \\
\hline \multirow{3}{*}{ Fat Sat } & 0.26 & There were \\
& Cerebrospinal fluid & 0.45 & $\begin{array}{l}\text { significant } \\
\text { differences }\end{array}$ \\
\cline { 2 - 3 } & Medula Spinalis & 0.43 & \\
\cline { 2 - 3 } & Discus & 0.296 & There were \\
& Meniscus & 0.26 & significant \\
TIRM & Cerebrospinal fluid & 0.45 & \\
\cline { 2 - 3 } & Medula Spinalis & 0.43 & \\
\cline { 2 - 3 } & Discus & 0.296 & \\
\cline { 2 - 3 } & Meniscus & & \\
\hline
\end{tabular}

CNR was the difference in SNR between adjacent organs or tissues. The calculated SNR differences were the Cerebrospinal fluid - Spinal cord, Cerebrospinal fluid - Discus, Spinal cord - Discus, Spinal cord - Meniscus, Discus - Meniscus. Table 5 presented the CNR value of the samples. 
TABLE 5.. CNR Results of Cervical MRI

\begin{tabular}{|c|c|c|c|c|c|c|}
\hline Technique & Sample & $\begin{array}{c}\text { Cerebrospinal } \\
\text { fluid } \\
\text { - Medula } \\
\text { Spinalis }\end{array}$ & $\begin{array}{l}\text { Cerebrospinal } \\
\text { fluid - Discus }\end{array}$ & $\begin{array}{c}\text { Medula Spinalis } \\
\text { - Discus }\end{array}$ & $\begin{array}{l}\text { Medula Spinalis } \\
\text { - Meniscus }\end{array}$ & $\begin{array}{c}\text { Discus - } \\
\text { Meniscus }\end{array}$ \\
\hline \multirow{5}{*}{ FAT SAT } & 1 & -167.46 & 0.52 & 264.72 & 190.96 & -73.76 \\
\hline & 2 & 18.75 & 47.82 & -0.98 & 4.77 & 5.75 \\
\hline & 3 & -10.04 & 14.55 & 83.07 & 95.45 & 12.38 \\
\hline & 4 & 18.01 & 45.93 & 5.57 & 11.75 & 6.17 \\
\hline & Average & -35.185 & 27.205 & 88.095 & 75.7325 & -12.365 \\
\hline \multirow{5}{*}{ TIRM } & 1 & -225.3 & 39.39 & 167.98 & 102.49 & -65.49 \\
\hline & 2 & 59.58 & 58.59 & 29.07 & 16.7 & -12.37 \\
\hline & 3 & -91.24 & -91.24 & 24.59 & 20.03 & -4.56 \\
\hline & 4 & 42.33 & 42.33 & 27.92 & 16.04 & -11.88 \\
\hline & Average & -53.6575 & 12.2675 & 62.39 & 38.815 & -23.575 \\
\hline
\end{tabular}

The CNR value was then tested using the Shapiro-Wilk Normality Test on SPSS, presented in Table 6. The data showed that $p>0.5$ and normally distributed.

TABLE 6.. Normality Test Results for CNR

\begin{tabular}{cllcc}
\hline \multirow{2}{*}{ Technique } & \multicolumn{1}{c}{ Tissue } & \multicolumn{2}{c}{ Shapiro-Wilk Normality Test } \\
\cline { 3 - 4 } & & Cignificance $(\boldsymbol{p})$ & Conclusion \\
\hline \multirow{3}{*}{ Fat Sat } & Cerebrospinal fluid-Medula Spinalis & 0.553 & Normal \\
\cline { 2 - 4 } & Medula Spinalis-Discus & 0.568 & Normal \\
\cline { 2 - 4 } & Medula Spinalis-Meniscus & 0.756 & Normal \\
\cline { 2 - 4 } & Discus-Meniscus & 0.657 & Normal \\
\cline { 2 - 4 } TIRM & Cerebrospinal fluid-Medula Spinalis & 0.845 & Normal \\
\cline { 2 - 4 } & Cerebrospinal fluid-Discus & 0.588 & Normal \\
\cline { 2 - 4 } & Medula Spinalis-Discus & 0.765 & Normal \\
\hline
\end{tabular}

After the data was proven to be normally distributed, the Paired T-Test was then carried out using SPSS to determine significant differences in each tissue. The Paired T-Test results showed in Table 7. As the significant value for all tissues was over 0.05 , there were significant differences in each tissue to other tissue.

TABLE 7.. Paired T-Test Significance Test Result of CNR

\begin{tabular}{|c|c|c|c|}
\hline \multirow{2}{*}{ Technique } & \multirow{2}{*}{ Tissue } & \multicolumn{2}{|c|}{ Paired T-Test } \\
\hline & & Significance $(p)$ & Conclusion \\
\hline \multirow{4}{*}{ Fat Sat } & $\begin{array}{l}\text { Cerebrospinal fluid-Medula } \\
\text { Spinalis }\end{array}$ & 0.315 & \multirow{4}{*}{$\begin{array}{l}\text { There were } \\
\text { significant } \\
\text { differences }\end{array}$} \\
\hline & Cerebrospinal fluid-Discus & 0.419 & \\
\hline & Medula Spinalis-Discus & 0.169 & \\
\hline & Medula Spinalis-Meniscus & 0.252 & \\
\hline \multirow{4}{*}{ TIRM } & Discus-Meniscus & 0.124 & \multirow{4}{*}{$\begin{array}{l}\text { There were } \\
\text { significant } \\
\text { differences }\end{array}$} \\
\hline & $\begin{array}{l}\text { Cerebrospinal fluid-Medula } \\
\text { Spinalis }\end{array}$ & 0.315 & \\
\hline & Cerebrospinal fluid-Discus & 0.419 & \\
\hline & Medula Spinalis-Discus & 0.169 & \\
\hline
\end{tabular}

The Fat Sat technique's average SNR and CNR values were higher than the TIRM technique, so the Fat Sat technique provided more optimal image quality than TIRM. However, this is only in theory and should be reanalyzed by a radiologist for more accurate results. 


\section{CONCLUSION}

3. There were significant differences in image quality of Cervical MRI using Turbo Invers Recovery magnitude (TIRM) and Fat Saturation (Fat Sat) indicated by the Paired T-Test result of SNR and CNR values with $p>0.05$.

4. The Fat Sat technique provided more optimal image quality than the TIRM technique..

\section{REFERENCE}

1. Notosiswoyo,Mulyono,2014,Media Litbang kesehatan pemanfaatan Magnetik Resonance imaging (MRI) sebagai sarana Diagnosa Pasien Volume XIV,nomor 3. 